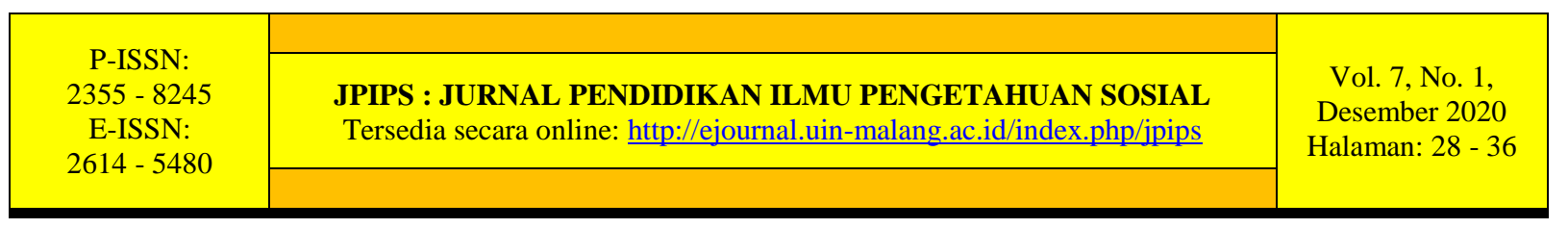

\title{
PERCEPTIONS OF HIGH SCHOOL STUDENTS IN EAST JAVA REGARDING IMPLEMENTATION SFH DURING THE COVID-19 PANDEMIC
}

\author{
Riyo Rosi Meisandy ${ }^{1}$, Sumarmi ${ }^{2}$ \\ ${ }^{1,2}$ State University of Malang \\ ${ }^{1}$ riyorosi.1907218@ students.um.ac.id, 2sumarmi.fis@um.ac.id
}

Diterima: 21-09-2020.; Direvisi: 15-11-2020; Disetujui: 22-12-2020

Permalink/DOI: 10.1886/jpips.v7i1.10354

Abstrak: Penelitian ini bertujuan untuk mengetahui: 1) kendala yang dihadapi siswa SMA di Jawa Timur dalam melaksanakan study from home; 2) Kesiapan fasilitas belajar bagi siswa SMA di Jawa Timur dalam melaksanakan study from home; 3) Platform atau aplikasi yang digunakan untuk pelaksanaan pembelajaran dari rumah bagi siswa SMA di Jawa Timur; 4) Kelebihan dan kekurangan penerapan study from home untuk siswa SMA di Jawa Timur. Penelitian ini menggunakan metode deskriptif dengan pendekatan kuantitatif. Data primer dalam penelitian ini diperoleh dari hasil pengisian kuisioner google form oleh 354 responden siswa SMA se-Jawa Timur. Hasil penelitian menunjukan bahwa kendala terbesar yang dihadapi siswa SMA dalam melaksanakan pembelajaran dari rumah sebesar 46,3\% adalah keterbatasan akses internet; $24,6 \%$ Kesulitan sinyal; 11,3\% terdapat perbedaan platform pembelajaran yang digunakan oleh masing-masing guru. Tingkat kesiapan siswa menghadapi study from home di masa pandemi menunjukkan bahwa 88,4\% siswa sudah siap karena ponsel atau gawainya mendukung pembelajaran online. Platform yang digunakan siswa SMA di Jawa Timur untuk mengakses pembelajaran online adalah: Whatsapp Group 70.6\%; Zoom 5.1\% dan Google Classroom 4\%. Kelebihan dari penerapan study from home adalah efisiensi waktu belajar, materi pembelajaran lebih beragam, serta tempat belajar yang fleksibel. Sementara kelemahan penerapan study from home adalah teknologi yang digunakan dalam pembelajaran sulit dimengerti siswa dan cenderung kurang efektif dalam kegiatan belajar mengajar.

\section{Keywords: Pembelajaran online; Persepsi siswa; Pandemi covid-19}

Abstract: This study aims to comprehend: 1) the obstacles confronted by high school students in East Java in implementing study from home; 2) Readiness of learning facilities for high school students in East Java in undertaking study from home; 3) The platform or application used for the implementation of study from home for high school students in East Java; 4) The advantages and disadvantages of implementing study from home for high school students in East Java. This study uses a descriptive method with a quantitative approach. In addition, primary data was obtained by using a questionnaire with google form in 354 student respondents from East Java. The result of this research was found that the biggest obstacles confronted by students in implementing study from 
home $46.3 \%$ were limited availability of internet access; $24.6 \%$ signal difficulty; $11.3 \%$ there are differences in the learning platforms used by each teacher. The level of readiness of students to confront study from home showed that $88.4 \%$ of students were ready because their cellphones or devices had supported the online learning. Platforms used for students in East Java to access online learning are:Whatsapp Group 70.6\%;Zoom 5.1\% and Google Classroom 4\%. The advantages of implementing study from home are time efficiency, more diverse learning materials, flexible places to study, while the disadvantage of implementing study from home is that the technology used in learning is difficult and ineffective in teaching and learning activities.

\section{Keywords: online learning; students perception; covid-19 pandemic}

\section{INTRODUCTION}

The transmission of COVID-19 in Indonesia is rapid enhancement. Since the first time a positive corona virus case was reported on March 2, 2020 (William, 2020), the number of positive cases has increased every day. In fact, data on 28 April 2020 cases of COVID-19 have expanded to 34 provinces, including 297 districts and cities. Totally from 514 districts and cities, 297 districts and cities in Indonesia have been confirmed that contracted the corona virus ( $\mathrm{Ri}, 2020)$. This shows that COVID-19 has prospered in infecting $60 \%$ of districts and cities from all regions of Indonesia.

In order to reduce the number of COVID-19 transmissions, the Indonesian government has occupied the decision to implement psychological distancing throughout Indonesia (Susilo et al., 2020). A circular issued by the government on March 18, 2020 explained that all indoor and outdoor activities in all sectors were temporarily postponed to reduce the spread of corona. The implementation of psychological distancing directly has a significant impact on several important sectors in Indonesia, including the educational sector.

Based on data from the Central Statistics Agency of East Java Province, the number of senior high schools in East Java Province in 2017 was 1533 and the number of students was 528,723 scattered in regencies and cities (Kementrian Pendidikan dan Kebudayaan, 2017). With the enactment of Circular Number 3 of 2020 concerning efforts to prevent Corona Virus Disease (COVID-19) in the Education Unit, all learning activities at the high school level are carried out online without face-to-face.

Study From Home through (digital learning) should be omitted E-Learning is determined as the most suitable learning method for high school students in East Java during the COVID-19 pandemic period (Wahyono et al., 2020). This learning activity is considered capable of supporting (Arifa, 2020). There are many benefits of using online education including communication, interaction between students, group development and a higher access to knowledge (Benta et al., 2014). Government policies in order to prevent transmission of COVID-19 without hindering teaching and learning activities. In its implementation, there are many obstacles faced by high school students in East Java related to the digital learning process during the Study From Home period. In this article, we will discuss the Perceptions of High School Students in East Java Regarding the Implementation of Study From Home During the COVID-19 Pandemic. 


\section{METHODS}

This research uses descriptive method with a quantitative approach. The tool that used to collect data in this study is a closed questionnaire with google form. The questionnaires were created and distributed by researchers to the respondents. Research data obtained from the results of filling out questionnaires by respondents. Respondents in this study were 354 high school students from 18 districts in East Java Province. From the results of filling out the questionnaire, it will be obtained data on the perceptions of high school students in East Java about study from home. The analysis technique that used is the percentage analysis technique, where after all the answers have been collected then the answers are tabulated. Data collection time was carried out for 3 months starting from April to June 2020.

\section{RESULTS AND DISCUSSION Results}

Respondents in this research were high school students in East Java. The number of respondents in this study were 354 students. as for the distribution of respondent's data is as follows:

Table 1. Age of Students

\begin{tabular}{lllcl}
\hline & $\mathbf{N}$ & Minimum & Maximum & Mean \\
\hline Age & 354 & 14 & 19 & 16,5
\end{tabular}

Based on table 1, the average age of students in this study is 16 years. For the highest age is 19 years and the lowest is 15 years.

Table 2. Grade of Students

\begin{tabular}{ccc}
\hline & Frequency & Percent \\
\hline Grade X & 161 & 45,5 \\
\hline Grade XI & 161 & 45,5 \\
\hline Grade XII & 32 & 9 \\
\hline Total & 354 & 100 \\
\hline
\end{tabular}

Respondents in this research were 161 class X students or $45.5 \%$, 161 class XI students or $45.5 \%$ and 32 XII class students or $9 \%$ of the total respondents, 354 people. Table 3. The Respondent's district of origin

\begin{tabular}{ccc}
\hline & Frequency & Percent \\
\hline Pacitan & 4 & 1,129944 \\
\hline Trenggalek & 9 & 2,542373 \\
\hline Tulungagung & 1 & 0,282486 \\
\hline Blitar & 6 & 1,694915 \\
\hline Kediri & 5 & 1,412429 \\
\hline Malang & 12 & 3,389831 \\
\hline Lumajang & 1 & 0,282486 \\
\hline Jember & 111 & 31,35593 \\
\hline Banyuwangi & 13 & 3,672316 \\
\hline Situbondo & 160 & 45,19774 \\
\hline Probolinggo & 17 & 4,80226 \\
\hline Pasuruan & 2 & 0,564972 \\
\hline Sidoarjo & 4 & 1,129944 \\
\hline Madiun & 2 & 0,564972 \\
\hline Bojonegoro & 2 & 0,564972 \\
\hline Kota Batu & 2 & 0,564972 \\
\hline Lamongan & 2 & 0,564972 \\
\hline Tuban & 1 & 0,282486 \\
\hline Total & 354 & 100 \\
\hline
\end{tabular}


The distribution of respondents in this study came from 18 districts in East Java Province, namely: 4 people or $1.12 \%$ from Pacitan, 9 people or $2.54 \%$ from Trenggalek, 1 person or $0.28 \%$ from Tulungagung, 6 people or $1.69 \%$ from Blitar, 5 people or $1.41 \%$ from Kediri, 12 people or $3.39 \%$ from Malang, 1 person or $0.28 \%$ from Lumajang, 111 people or $31.35 \%$ from Jember, 13 people or $3.67 \%$ from Banyuwangi, 160 people or $45.19 \%$ from Situbondo, 17 people or $4.80 \%$ from Probolinggo, 2 people or $0.54 \%$ from Pasuruan, 4 people or $1.13 \%$ from Sidoarjo, 2 people or $0.56 \%$ from Madiun, 2 people or $0.56 \%$ from Bojonegoro, 2 people or $0.56 \%$ from Batu City, 2 people or $0.56 \%$ from Lamongan, and 1 person or $0.28 \%$ from Tuban.

Based on the results of data processing. Overall perceptions of high school student in East Java regarding implementation study from home during the Covid-19 pandemic can be describe as follows:

Figure 1. Obstacles High school students in implementing SFH

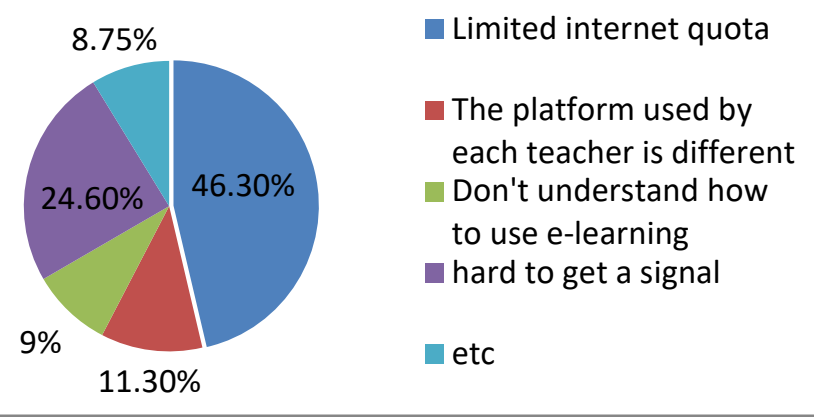

Figure 2. Readiness of online learning facilities

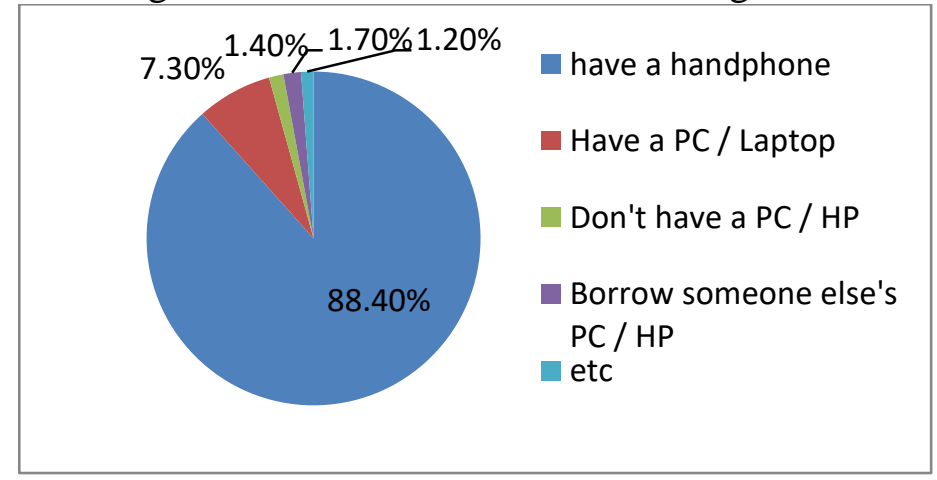

Figure 3. Online Learning Platform or Application used

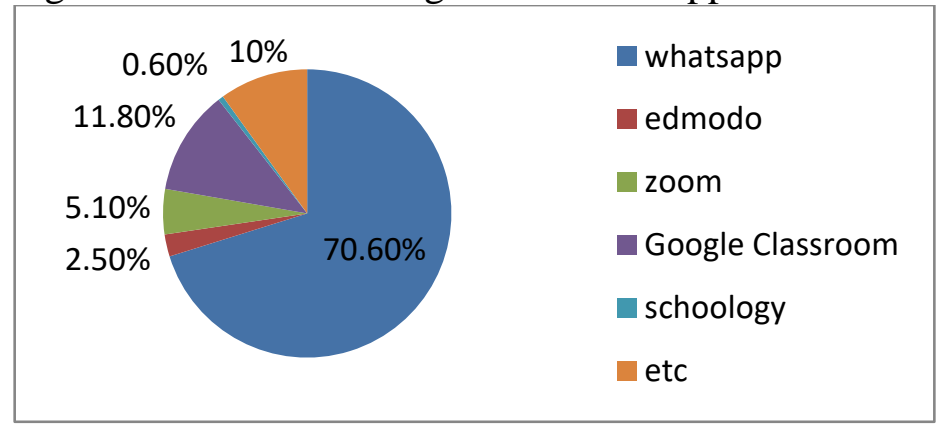




\section{Discussion}

The effect of the COVID-19 pandemic has affected the education sector since 17 April 2020. Nearby 1.72 billion students globally cannot study in school due to the restriction of activities (Nasir Mustafa, 2020). There are 528,723 high school students in East Java, Indonesia (Kementrian Pendidikan dan Kebudayaan, 2017). The East Java provincial government has responded to the spread of the COVID-19 virus by changing face-to-face learning in schools in East Java and replacing it with online learning.

Distance learning uses information and communication technology. Laptops, cellphones and internet connections are the paramount requirements for the continuity of online learning (Sandars et al., 2020). In East Java, online learning has been running since March 16, 2020. Both teachers and students are forced to apply online learning methods so that the teaching and learning process continues (King, 2001). At the beginning of its implementation, there were many obstacles due to the unpreparedness of teachers and students for the new online learning methods applied during the pandemic, particularly in areas that have limited access to the internet and the devices used as learning tools.

\section{A. Obstacles in Online Learning of High School students}

The expansive nature of the Internet and the accessibility of technology have generated a surge in the demand for web based teaching and learning (Gilbert et al., 2015). The implementation of Study From Home based on e-learning is indeed very surprising for students and teachers in East Java. Most teachers in East Java have never implemented online learning. Many teachers do not support online instruction because they do not believe it actually solves difficult teaching and learning problems (Chaeruman, 2018). While others are concerned about the many barriers that hinder effective online teaching and learning. On the other hand, studies have shown that online learning offers a major breakthrough in teaching and learning since it facilitates the exchange of information and expertise while providing opportunities for all types of learners in distant or disadvantaged locations (Appanna, 2018). However, the conditions of the Covid-19 pandemic have forced the teachers to use online platforms in the learning process.

Based on figure 1, we can comprehend that the biggest obstacle experienced by high school students in East Java, which is $46.3 \%$, is the limited internet quota. This happens because not all schools provide subsidized quotas to be used in online learning. Several areas in East Java also have problems regarding high internet quota prices. Moreover, Despite of the dynamic development of ICTs and decreasing prices of personal computers, laptops, smartphones, tablets and other devices, there is still quite a considerable imbalance among students as far as material equipment and Internet connectivity is concerned (J. Zounek \& Sudický, 2012).

Another obstacle experienced by high school students in East Java is the difficulty of getting an internet signal. This is because some areas in East Java are 3T or outermost, underdeveloped, frontier areas. Menteri Desa Pembangunan Daerah Tertinggal dan Transmigrasi Republik Indonesia, 2017 mentions the criteria for underdeveloped areas based on the community's economy, human resources (HR), facilities and infrastructure, regional financial capacity, accessibility, and regional characteristics. It is not surprising that the difficulty of accessing internet signals is an obstacle in the continuation of Study From Home. based on the questionnaire $24.6 \%$ of students in East Java have difficulty getting an Internet signal. Ku \& Lohr (2003) assert that technological problems commonly faced by students in e-learning including frequent 
disruption to the internet connection, slow loading, and incompatibility of software and hardware. Hence, these technical problems, especially the slow internet connection, were a drawback that hamper the implementation of e-learning.

The policy of the regional government of East Java Province regarding online learning makes teachers compete to innovate in online learning. The absence of standardization in using the official platform is an obstacle for students. Another important consideration of online learning is the issue of communication and information overload. Too many contacts and continuous communication via a variety of channels and services may cause considerable distraction preventing students from focused, concentrated learning and task solving (Jiří Zounek, 2009). As many as $11.3 \%$ of students in East Java have difficulty using multiple platforms. Each subject teacher uses a different platform according to the needs of each lesson. hence students have to install several different applications.

Technology, Information and Communication subject in high school has been eliminated. This causes obstacles in the form of difficulty for students to understand elearning tools. Even though in the digital era knowledge of information and communication technology is very important. E-learning requires technological skill. The next drawback perceived by the participants regarding the implementation of elearning was that this technique required a decent technological skill (Rahmawati, 2016). Diagram 1 demonstrates the level of difficulty in understanding the use of e learning high school in East Java is $9 \%$. It means that the teachers need to provide students with sufficient knowledge and skills about the software or application used for e-learning. In order to assure the successful e-learning implementation, teachers should introduce the application to the students in the beginning of the implementation, demonstrate them how to operate it, and provide guidelines about what the students need to accomplish, so that the students become familiar and are not confused.

\section{B. The readiness of high school students' online learning facilities}

Students are one of the key elements during the implementation of e-learning systems within high school (Gathegi et al., 2013). To be able to build solid and effective e-learning systems, it is important to know the level of students' readiness. The readiness of student learning with new methods is important to support the continuity of online learning. It has been decided that online learning is a way out for the implementation of formal education programs in Indonesia during the COVID-19 pandemic.

Based on the data in figure 2, it can be seen that $88.4 \%$ of students in East Java already have mobile phones that support online learning. $7.3 \%$ of students in East Java have a PC / Laptop that is ready to be used to support an internet-based learning system. However, there are still $1.4 \%$ students who cannot access online learning because they do not have cellphones or PCs that can support the learning process. $1.7 \%$ of students in East Java choose to borrow cellphones or PCs to use in online learning.

Based on these data, students in East Java are ready to face the digital learning system in terms of facilities. The total number of students who have cellphones or PCs / laptops that support online learning is $95.7 \%$. However, the school needs to think about how alternative learning can be applied to students who do not have cellphones or access to online learning. 
C. High school students' Online Learning Platform or application

E-learning platforms are constantly changing; they have transformed the everyday life of teachers and students. An e-learning platforms study, from a methodical, systemic approach that identifies the dimensions, specifications and the essential criteria for the evaluation of these platforms is necessary (Ouadoud et al., 2016). Since the Covid-19 pandemic, there have been many learning platforms that can be accessed for free. However, not all teachers can afford and take advantage of the available free learning platforms.

Based on the data in the figure 3, it can be seen that $70.6 \%$ of online learning that takes place in high schools in East Java uses the Whatsapp platform as an online learning medium, $11.8 \%$ uses Google Classroom as an online learning medium, $5.1 \%$ uses Zoom Meeting as a learning medium. online, $2.5 \%$ use edmodo as an online learning medium, $0.6 \%$ use schoology as an online learning medium and $10 \%$ use random applications.

From the results of the questionnaire, it can be seen that most teachers still have not used the digital platform which functions as a learning medium. Teachers prefer to use the WhatsApp chat application as a medium of communication in online learning which of course has many shortcomings when compared to learning platforms such as edmodo, schoology, google classroom or face-to-face applications such as Zoom.

\section{The advantages and disadvantages}

Learning enhanced by online technologies follows the principle of "anywhere" and "anytime" (Profile, 2016). Personalization and flexibility are the leading keywords when we think about online-based learning. In the application of study from home, of course, there are more disadvantages compared to the advantages. Without any special preparation regarding online learning techniques teachers and students are required to adapt themselves independently to the online learning process. Online learning is deemed ineffective because it divides the focus of students who initially only learn now must also focus on applications or learning platforms.

However, behind the shortcomings felt by teachers and students during online learning, there are several benefits that are felt by students and teachers, namely 1) time efficiency because students do not need to go to school; 2) more diverse learning materials that can be accessed via internet platforms; 3) study anywhere, not necessarily at school.

\section{CONCLUSIONS}

The study from home process through online learning is one solution to limiting activities as an effort to prevent virus transmission during the COVID-19 pandemic. At the high school level in East Java, there are still many obstacles related to the use of Information and Communication Technology in education. Each student's limited internet access is the biggest problem in the online learning process. Apart from this, students are hampered by the instability of the internet signal in several areas of East Java. students cannot access many learning platforms because of the limited functionality of their cellphones. Besides this, through online learning students can access more diverse information. students are also free to search for information that can be accessed anytime and anywhere. 


\section{ACKNOWLEDGMENTS}

We would like to thank the Indonesia Endowment Fund of Education (LPDP) for financial support. We would also like to all respondents and colleagues who have helped in the process of collecting this research data.

\section{REFERENCES}

Appanna, S. (2018). A Review of Benefits and Limitations of Online Learning in the Context of the Student, the Instructor and the Tenured Faculty A Review of Benefits and Limitations of Online Learning in the Context of the Student, the Instructor, and the Tenured Faculty. December.

Arifa, F. N. (2020). Tantangan Pelaksanaan Kebijakan Belajar Dari Rumah Dalam Masa Darurat Covid-19. Info Singkat;Kajian Singkat Terhadap Isu Aktual Dan Strategis, $X I I(7 / I), \quad 6 . \quad$ http://berkas.dpr.go.id/puslit/files/info_singkat/Info Singkat-XII-7-IP3DI-April-2020-1953.pdf

Benta, D., Bologa, G., \& Dzitac, I. (2014). E-learning platforms in higher education. Case study. Procedia Computer Science, 31(July), 1170-1176. https://doi.org/10.1016/j.procs.2014.05.373

Chaeruman, U. A. (2018). Mendorong Penerapan E-Learning Di Sekolah. Jurnal Teknodik, 12(1), 025. https://doi.org/10.32550/teknodik.v12i1.417

Gathegi, J. N., Tonta, Y., \& Eds, Z. T. (2013). Students readiness for e-learning: An assessment on Hacettepe University Department of Information Management. Communications in Computer and Information Science, 423(September 2017), 137 147. https://doi.org/10.1007/978-3-662-44412-2

Gilbert, B., John, S., \& College, F. (2015). Online Learning Revealing the Benefits and Challenges How has open access to Fisher Digital Publications benefited you?

Kementrian Pendidikan dan Kebudayaan. (2017). Ikhtisar Data Pendidikan Tahun 2016/2017. 47.

King, F. B. (2001). Defining Distance Learning and Distance Education Frederick B . King , Michael F. Young, Kelly Drivere-Richmond, P. G. Schrader The University of Connecticut Neag School of Education Submitted to : Educational Technology Review Frederick King : rking. January.

Ku, B. H., \& Lohr, L. L. (n.d.). A Case Study of Chinese Students '.

Menteri Desa Pembangunan Daerah Tertinggal dan Transmigrasi Republik Indonesia. (2017). Keputusan Menteri Desa, PDTT. In Kementerian Desa Pembangunan Daerah Tertinggal dan Rransmigrasi https://doi.org/10.1017/CBO9781107415324.004

Nasir Mustafa. (2020). Impact of the 2019 - 20 coronavirus pandemic on education. International Journal of Health Preferences Research, 1-36.

Ouadoud, M., Chkouri, M. Y., Nejjari, A., \& El Kadiri, K. E. (2016). Studying and comparing the free e-learning platforms. Colloquium in Information Science and Technology, CIST, O(March 2018), 581-586. https://doi.org/10.1109/CIST.2016.7804953

Profile, S. E. E. (2016). Heads in the Cloud: Pros and Cons of Online Learning . December.

Rahmawati, F. (2016). E-Learning Implementation: Its Opportunities and Drawbacks Perceived by EFL Students. Journal of Foreign Languange Teaching and Learning, 1(1). https://doi.org/10.18196/ftl.111

Ri, K. K. (2020). COVID-19 dalam Angka. 
Sandars, J., Correia, R., Dankbaar, M., de Jong, P., Goh, P. S., Hege, I., Masters, K., Oh, S.-Y., Patel, R., Premkumar, K., Webb, A., \& Pusic, M. (2020). Twelve tips for rapidly migrating to online learning during the COVID-19 pandemic. MedEdPublish, 9(1), 1-14. https://doi.org/10.15694/mep.2020.000082.1

Susilo, A., Rumende, C. M., Pitoyo, C. W., Santoso, W. D., Yulianti, M., Herikurniawan, H., Sinto, R., Singh, G., Nainggolan, L., Nelwan, E. J., Chen, L. K., Widhani, A., Wijaya, E., Wicaksana, B., Maksum, M., Annisa, F., Jasirwan, C. O. M., \& Yunihastuti, E. (2020). Coronavirus Disease 2019: Tinjauan Literatur Terkini. Jurnal Penyakit Dalam Indonesia, 7(1), 45. https://doi.org/10.7454/jpdi.v7i1.415

Wahyono, P., Husamah, H., \& Budi, A. S. (2020). Guru profesional di masa pandemi COVID-19: Review implementasi, tantangan, dan solusi pembelajaran daring. Jurnal Pendidikan Profesi Guru, 1(1), 51-65. https://doi.org/10.22219/JPPG.V1I1.12462

William, E. (2020). Pandemi COVID-19 dalam Perspektif Demografi Sosial Dinamika Mortalitas dalam Kejadian Luar Biasa: Studi Kasus Pandemi Coronavirus Disease 2019 ( COVID-19) Tahun 2020 Disusun oleh : Jurnal Universitas Indonesia, 2(1), 1-19. https://doi.org/10.13140/RG.2.2.36248.83200

Zounek, J., \& Sudický, P. (2012). E-learning: učení (se) s online technologiemi. 226.

Zounek, Jiř́i. (2009). E-learning - jedna z podob učení v moderní společnosti. EPedagogium, 11(1), 175-177. https://doi.org/10.5507/epd.2011.016 